\title{
A Rare Case: Mucous Membrane Plasmacytosis in the Larynx
}

\section{Nadir Bir Olgu: Larinkste Mukozal Plazmasitoz}

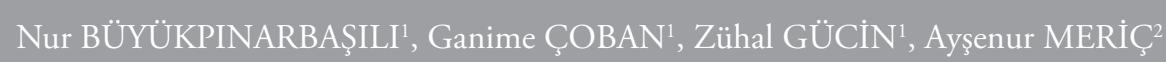

${ }^{1}$ Department of Pathology, Bezmialem Vakif University, Faculty of Medicine, Istanbul, Turkey

${ }^{2}$ Department of Otorhinolaryngology, Bezmialem Vakif University, Faculty of Medicine, Istanbul, Turkey

\section{ABSTRACT}

Mucous membrane plasmacytosis is a rare reactive process characterized by plasma cell infiltration of mucous membranes for unknown reasons. It may be confused with malignancy because of its exophytic structure and pavement appereances. A laryngeal polypoid lesion was sent to the pathology department, clinically called fibroma, and presented to emphasize the diagnostic and differential diagnostic criteria.

Key Words: Larynx, mass, plasmacytosis, mucositis

\section{ÖZET}

Mukozal plazmasitoz sebebi bilinmeyen, mukozaların plazma hücreleri ile infiltre olduğu nadir görülen reaktif bir durumdur. Makroskopik olarak kaldırım taşı ve ekzofitik lezyon oluşturabildiğinden malignite ile karıştırılabilir. Burada fibrom ön tanısı ile patoloji birimine gönderilen laringeal lezyon, tanı ve ayırıcı tanı kriterleri ile sunulmuştur.

Anahtar Sözcükler: Larinks, kitle, plazmasitoz, mukozit

\section{Giriş}

Mukozal plazmasitoz sebebi bilinmeyen, mukozaların plazma hücreleri ile infiltre olduğu nadir görülen reaktif bir durumdur $(1,2)$. İlk defa genital bölgede tarif edilen lezyon; oral mukoza, damak, dil, farinks, larinks, dudak ve trakeada da görülebilir $(3,4)$.

\section{Olgu Sunumu}

4 aydan beri ses kısıklığı olan 18 yaşında erkek hasta, nefes almada güçlük şikayeti ile acil servise başvurdu. Muayenesinde subglottik bölgede yaklaşık $2 \times 2 \mathrm{~cm}$ ölçüde kitle tespit edildi ve operasyon planland. Genel sistem muayenesinde özellik görülmedi. Yapılan tetkiklerinde lökositoz, lenfopeni ve AST (Aspartat aminotransferaz) yüksekliği saptandı. Operasyonda anterior komissürün $1 \mathrm{~cm}$ altında, $2 \mathrm{~cm}$ çapında, subglottik kitle eksize edilerek fibrom ön tanısıyla birimimize gönderildi. Makroskopik incelemede, $2 \times 1,7 \times 1,5 \mathrm{~cm}$ ölçüde polipoid lezyonun kesitinde nodüler görünümde, kirli beyaz renkte alanlar görüldü. Mikroskopik incelemede epitel altında plazma hücrelerinden zengin, lenfositlerin eşlik ettiği mononükleer iltihabi hücre infiltrasyonu mevcuttu. Ayrıca fibrozis, damar endotel proliferasyonu ve miksoid dejenerasyon alanları görüldü (Resim 1 ve 2). Mikroskopik olarak ayırıcı tanıya laringeal sifiliz, rhinoskleroma, atipik mikobakterial enfeksiyon, inflamatuar myofibroblastik tümör ve plazmasitom alındı. Uygulanan immünhistokimyasal çalışmada (Ventana Benchmark XT-USA) CD138 (monoklonal, klon C1B-1D4, Biogenex) ile pozitif olan (Resim 3) plazma hücrelerinin Kappa (monoklonal, klon L1C1, Neomarkers) ve Lambda (monoklonal, klon HP6054, Neomarkers) ile poliklonal olduğu sap- 


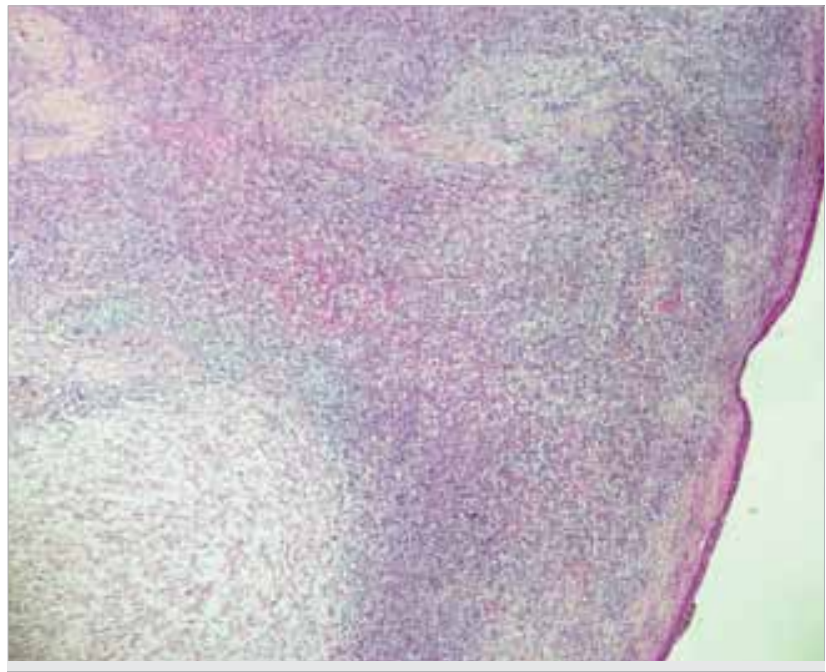

Resim 1. Epitel altında fibrotik ve miksoid görünümlü alanlar, mononükleer iltihabi hücre infiltrasyonu (H\&EX40)

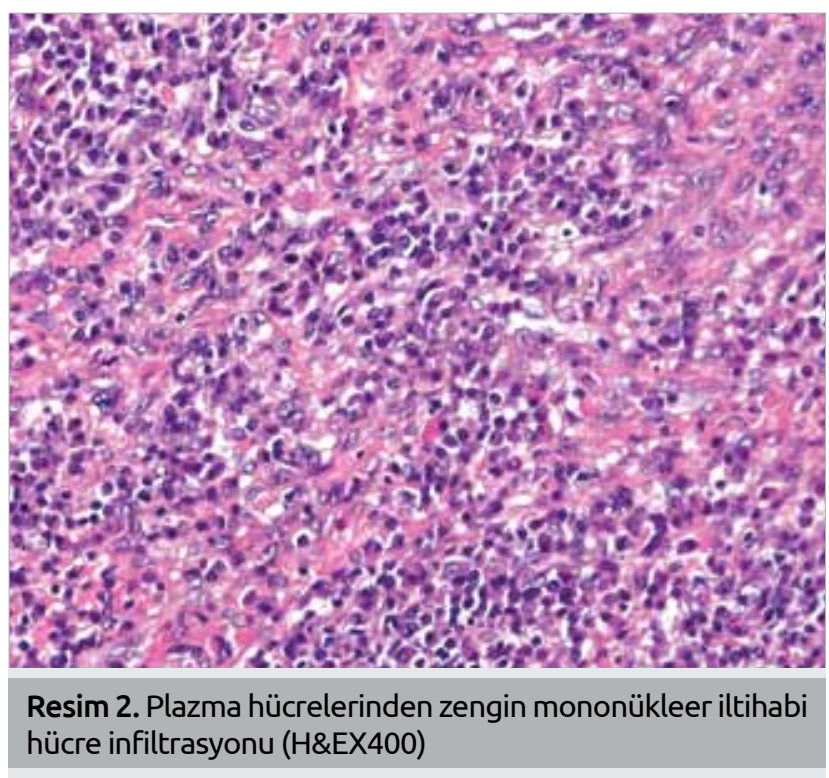

tandı. Plazma hücrelerinin poliklonal oluşu olguyu plazmasitom tanısından uzaklaştırdı. İmmünhistokimyasal olarak uygulanan ALK (Anaplastik lenfoma kinaz) (monoklonal, klon 5A4, Biocare) ile ekspresyon görülmemesi ile inflamatuar myofibroblastik tümör tanısı dışlandı. Histokimyasal çalışmada (Ventana Bencmark Special Stains-USA) PAS (Ventana) ve Grocott (Ventana) ile enfeksiyöz bir ajan izlenmedi. Sonuç olarak; olgu "Mukozal plazmasitoz (plazma hücreli mukozit)" olarak yorumlandı. Hasta onamı alındı.

\section{Tartışma}

Mukozal plazmasitoz, mukozalarda yoğun plazma hücre infiltrasyonuyla karakterize nadir görülen idiopatik bir durumdur. İlk defa Zoon tarafından 1952 yılında glans peniste tarif edilmiştir. Bu fenomen aynı zamanda vulva, bukkal mukoza, damak, nazal bölge, gingiva, dudak, dil, epiglot, larinks ve diğer orifisial yüzeylerde görülebilmektedir (3, 4). Ancak üst aerodigestif sistemde seyrektir. Nadiren multifokal de

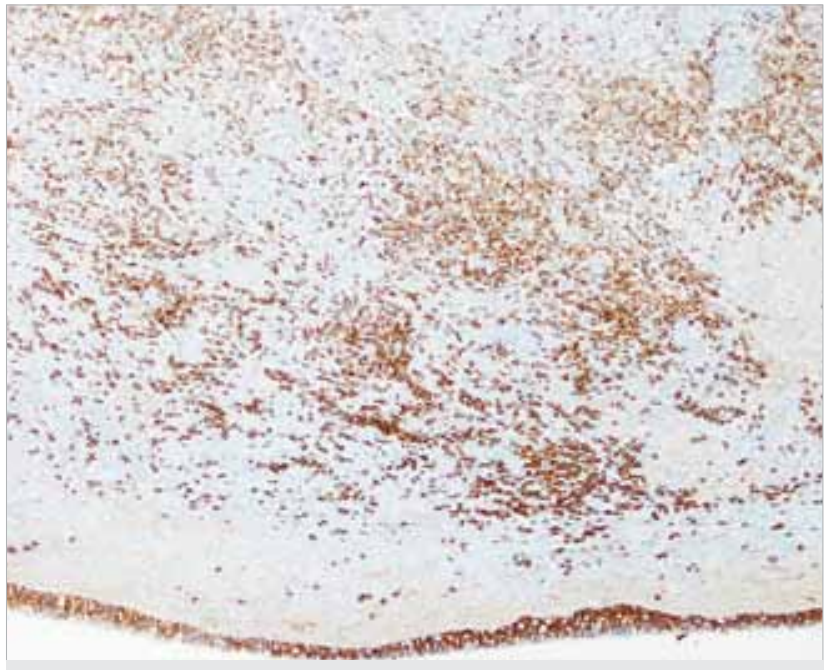

Resim 3. İmmünhistokimyasal olarak CD138 ile pozitiflik (X400)

olabilir. Yerleşim yerine göre klinik bulgu verir (3). Klasik klinik prezentasyonu verrüköz, kaldırım taşı, papillomatöz veya kadifemsi görünümde yoğun eritemli mukoza şeklindedir. Mukozal plazmasitoz benign bir lezyondur fakat ayırıcı tanıdaki lezyonlar nedeniyle de önem arz etmektedir $(5,6)$. Mikroskopik olarak ayrıcı tanıya laringeal sifiliz, rhinoskleroma, sarkoidoz, atipik mikobakterial enfeksiyon, inflamatuar myofibroblastik tümör, Rosai-Dorfman hastalığı ve plazmasitom girmektedir. Tanı, ayırıcı tanıya alınan diğer durumların histolojik, serolojik ve kültür yardımı ile dışlanması sonucu konulur (3).

\section{Sonuç}

Larinkste kitle oluşturarak semptoma neden olan ve klinik olarak tümör ayırıcı tanıya alınan olgularda, tümörü taklit eden reaktif lezyonların akılda tutulması önemlidir.

Informed Consent: Written informed consent was obtained from the patient who participated in this case.

Peer-review: Externally peer-reviewed.

Author Contributions: Concept - N.B., G.Ç., Z.G.; Design - N.B., Z.G.; Supervision - N.B., G.Ç., Z.G., A.M.; Funding - N.B., G.Ç., Z.G., A.M.; Materials - N.B., G.Ç., Z.G., A.M.; Data Collection and/or Processing N.B., G.Ç., Z.G., A.M.; Analysis and/or Interpretation - N.B., G.Ç., Z.G., A.M.; Literature Review - N.B., G.Ç.; Writing - N.B., G.Ç., Z.G.; Critical Review - N.B., Z.G.

Conflict of Interest: No conflict of interest was declared by the authors.

Financial Disclosure: The authors declared that this case case has received no financial support.

Hasta Onamı: Yazılı hasta onamı bu olguya katılan hastadan alınmıştır.

Hakem Değerlendirmesi: Dış bağımsız.

Yazar Katkıları: Fikir - N.B., G.Ç., Z.G.; Tasarım - N.B., Z.G.; Denetleme - N.B., G.Ç., Z.G., A.M.; Kaynaklar - N.B., G.Ç., Z.G., A.M.; Malzemeler 
- N.B., G.Ç., Z.G., A.M.; Veri Toplanması ve/veya İşlemesi - N.B., G.Ç., Z.G., A.M.; Analiz ve/veya Yorum - N.B., G.Ç., Z.G., A.M.; Literatür Taraması - N.B., G.Ç.; Yazıyı Yazan - N.B., G.Ç., Z.G.; Eleştirel İnceleme - N.B., Z.G.

Çıkar Çatışması: Yazarlar çıkar çatışması bildirmemişlerdir.

Finansal Destek: Yazarlar bu olgu için finansal destek almadıklarını beyan etmişlerdir.

\section{Kaynaklar}

1. Timms MS, Sloan P, Balzan AP. Idiopathic plasmacytosis of the oral and supraglottic mucosa. J Laryngol Otol 1988; 102: 646-8. [CrossRef]

2. Puvanendran M, Lieder A, Issing W. Plasma Cell Mucositis of Oroand Hypopharynx: A case report. Case Rep in Otolaryngol 2012; 2012: 304136
3. Bharti R and Smith DR. Mucous membrane plasmacytosis: A case report and review of the literature. Dermatology Online Journal 2003; 9: 15

4. Ferreiro JA, Egorshin EV, Olsen KD, Banks PM, Weiland LH. Mucous membrane plasmacytosis of the upper aerodigestive tract. A clinicopathologic study. Am J Surg Pathol 1994; 18: 1048-53. [CrossRef]

5. Pepper T, Shekar K, Singh M, Brennan PA. Squamous cell carcinoma arising in mucosal plasmacytosis. British Journal of Oral and Maxillofacial Surgery 2010; 48: 208-10. [CrossRef]

6. Najarian DJ, Rao BK, Pappert AS. A case of mucous membrane plasmacytosis successfully treated with cryotherapy. Dermatol Online J 2008; 14: 6. 